\title{
NEW
}

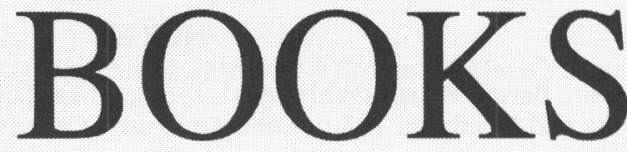

the

PARACAS RITUAL ATTIRE

Symbols of Authority in Ancient Peru By Anne Paul

"This book should become the outstanding work on Paracas textiles, one of the glamor stocks of Pre-Columbian art." -Patricia Rieff Anawalt, Museum of Cultural History, Los Angeles.

Vol. 195 in The Civilization of the American Indian Series.

26 color \& 165 b\&w illus. $7 \times 10 . \$ 48.50$

\section{MAYA HISTORY AND}

\section{RELIGION}

By J. Eric S. Thompson

New Fwd. by David M. Pendergast

\& Elizabeth Graham

"Beautifully written and well-documented."

- Library Journal.

Vol. 99 in The Civilization of the American Indian Series. Paper, \$14.95

\section{THE LANGUAGE OF}

\section{SPANISH DANCE}

By MATTEO Marcellus Vittucci

With Carola Goya

This groundbreaking work on the Spanish dance is indispensable. ". . . excellent book." -Kirsten Ralov. ". . . a most welcome and valuable book...'-Dame Alicia Markova. "It fills a big gap. . . . a delight and a 'must'."'-Dame Margot Fonteyn. 49 photos, 101 drawings. $7 \times 10$ $\$ 65.00$

\section{SIXTH PALENQUE}

ROUND TABLE, 1986

Merle Greene Robertson, General Editor An essential tool for Maya scholars and students. 321 illus. $\$ \mathbf{6 5 . 0 0}$

\section{AZTEC THOUGHT AND \\ CULTURE}

A Study of the Ancient Nahuatl Mind

By Miguel Leon-Portilla

Tr. by Jack Emory Davis

". . . a superb analysis of how and why the Aztecs developed as they did.'Library Journal.

Vol. 67 in The Civilization of the American Indian Series

Paper, \$13.95

\section{THE TREATY OF GUADALUPE} HIDALGO

A Legacy of Conflict

By Richard Griswold del Castillo

A fresh look at one of the most important treaties ratified by the United States and Mexico. \$22.95

THE FOLKLORE OF SPAIN IN THE AMERICAN SOUTHWEST

Traditional Spanish Folk Literature

in Northern New Mexico and

Southern Colorado

By Aurelio M. Espinosa

Ed. by J. Manuel Espinosa

". . . a landmark contribution to the humanities." -Southwestern Historical Quarterly.

Paper, \$13.95

\section{CALIFORNIA IN 1792}

A Spanish Naval Visit

By Donald C. Cutter

The first translation of two young Spanish explorers' account of California during the golden age of the Spanish colony.

Vol. 71 in The American Exploration and Travel Series.

\section{$\$ 24.95$}

\section{INDIAN CLOTHING BEFORE CORTES}

Mesoamerican Costumes from the Codices By Patricia Rieff Anawalt Fwd. by H. B. Nicholson

Charts by Jean Cuker Sells

"No other study brings so much material together in such a detailed way." - Choice. 16 color plates, 63 figs, 230 examples, 23 luus charts. $9 \times 12$. Paper, $\$ \mathbf{3 7 . 9 5}$

\section{TIME AND REALITY IN THE THOUGHT OF THE MAYA \\ By Miguel León-Portilla}

Fwd. by Sir J. Eric S. Thompson

Tr. Charles L. Boiles \& Fernando Horcasitas In one of his most notable works, LeónPortilla explores the Maya Indians' remarkable concepts of time. ". . . a classic on the Maya."-Times of the Americas.

Vol. 190 in The Civilization of the American Indian Series.

6 b\&w plates, 34 figs. Paper, $\$ 13.95$

Write for free catalog. From your bookseller, or . . .

\section{University of Oklahoma Press}

Dept. MAS6/1005 Asp Ave./Norman, OK 73019-0445

For books add: $\$ 1.50 \mathrm{P} / \mathrm{H}$. Take: Visa/MC/AE/chks 


\section{OFFICERS OF THE SOCIETY FOR AMERICAN ARCHAEOLOGY}

President: JEREMY A. SABLOFF, Department of Anthropology, University of Pittsburgh, Pittsburgh, PA 15260.

President-elect: PRUDENCE M. RICE, Florida Museum of Natural History, Department of Anthropology, University of Florida, Gainesville, FL 32611.

Secretary: LYNNE GOLDSTEIN, Department of Anthropology, University of WisconsinMilwaukee, WI 53201.

Secretary-elect: SHEREEN LERNER, State Historic Preservation Office, Arizona State Parks, 800 W. Washington, Suite 415, Phoenix, AZ 85007.

Treasurer: MARK P. LEONE, Department of Anthropology, University of Maryland, College Park, MD 20742.

Editor American Antiquity: J. JEFFERSON REID, Department of Anthropology, University of Arizona, Tucson, AZ 85721 .

Executive Board Members: ROBERT L. BETTINGER, Department of Anthropology, University of California-Davis, Davis, CA 95616; JAMES A. BROWN, Department of Anthropology, Northwestern University, Evanston, IL 60208-1310; MARGARET W. CONKEY, Department of Anthropology, University of California, Berkeley, CA 94720; BRIAN M. FAGAN, Department of Anthropology, University of California, Santa Barbara, CA 93106; MARK J. LYNOTT, Midwest Archeological Center, National Park Service, Federal Building, Room 474, 100 Centennial Mall North, Lincoln, NE 68508; JERALD T. MILANICH, Florida Museum of Natural History, Museum Road, Gainesville, FL 32611.

Executive Director: JEROME A. MILLER, Society for American Archaeology, 808 17th St., N.W., Suite 200, Washington, DC 20006.

General Counsel: RICHARD A. FULTON, White, Fine \& Verville, Washington, DC.

\section{LATIN AMERICAN ANTIQUITY SUBSCRIPTION INFORMATION}

\begin{tabular}{lcc}
\multicolumn{1}{c}{ Rates } & A & B \\
Society members & $\$ 40.00$ & $\$ 25.00$ \\
Student and retired members & 30.00 & - \\
Nonmembers and institutions & 70.00 & 25.00
\end{tabular}

Schedule A: Applies to subscribers in Australia, Canada, Japan, New Zealand, the United States, and Western Europe.

Schedule B: Applies to subscribers in Latin America, Portugal, Spain, and all other countries.

Subscriptions should be sent to the Society for American Archaeology, 808 17th Street, N.W., Suite 200, Washington, DC 20006. Prepayment is required, payable in U.S. funds.

\section{NOTICE TO AUTHORS}

Latin American Antiquity publishes papers on the archaeology, prehistory, and ethnohistory of Latin America, i.e., those countries - primarily Spanish speaking-comprising Mesoamerica, Central America, and South America, together with culturally affiliated adjacent regions. Submissions (articles or reports) may be in either English or Spanish. Authors should submit an original and three copies of their manuscripts, along with an abstract in both English and Spanish, to the editor. Latin American Antiquity follows American Antiquity style except for the omission of accents on place names in Spanish. For additional information or clarification consult a recent issue of American Antiquity, or contact the managing editor. 


\section{CONTENTS}

\section{ARTICLES}

Some Formal Correspondences Between the Imperial Architecture of the Wari and Chimu Cultures of Ancient Peru

The Productivity of Maguey Terrace Agriculture in Central Mexico During the Aztec Period

Restos Humanos Asociados a la Pirámide de Akapana (Tiwanaku, Bolivia)

Differential Bone-Refuse Accumulation in Food-Preparation and Traffic Areas on an Early Ecuadorian House Floor

Ancient and Modern Maya Exploitation of the Jute Snail

(Pachychilus) 